\title{
James Francis Kenney, 1884-1946: Founder of the Canadian Catholic Historical Association
}

\section{Glenn T. Wright}

Volume 50, numéro 1, 1983

Bilan de l'histoire religieuse au Canada

Canadian Catholic History: A survey

URI : https://id.erudit.org/iderudit/1007033ar

DOI : https://doi.org/10.7202/1007033ar

Aller au sommaire du numéro

Éditeur(s)

Les Éditions Historia Ecclesiæ Catholicæ Canadensis Inc.

ISSN

0318-6172 (imprimé)

1927-7067 (numérique)

Découvrir la revue

Citer cet article

Wright, G. T. (1983). James Francis Kenney, 1884-1946: Founder of the

Canadian Catholic Historical Association. Sessions d'étude - Société canadienne d'histoire de l'Église catholique, 50(1), 11-45. https://doi.org/10.7202/1007033ar

Tous droits réservés @ Les Éditions Historia Ecclesiæ Catholicæ Canadensis Inc., 1983
Ce document est protégé par la loi sur le droit d'auteur. L'utilisation des services d'Érudit (y compris la reproduction) est assujettie à sa politique d'utilisation que vous pouvez consulter en ligne.

https://apropos.erudit.org/fr/usagers/politique-dutilisation/ 


\title{
James Francis Kenney, 1884-1946 \\ Founder of the Canadian Catholic Historical Association
}

\author{
by Glenn T. WRIGHT \\ Public Archives of Canada. Ottawa
}

On 14 June 1936, James Francis Kenney was presented with an honorary Doctor of Law degree by the University of Ottawa in recognition of his scholarly achievements as an historian and for his role in founding the Canadian Catholic Historical Association (CCHA) in 1933. In the course of his acceptance speech, Dr. Kenney described historical research as the search for truth, emphasizing that "the beginning of knowledge is devotion to truth." It was in this spirit, he continued, that the CCHA had set forth "on its own modest, but potentially, most important crusade." To illustrate his meaning, he quoted from a letter that St. Columbanus had written to Pope Gregory the Great in the year 600 A.D.: "Antiquus error est, sed semper antiquior est veritas." Dr. Kenney was of the firm belief that this phrase was at once "the explanation, the justification and the inspiration of historical research." I James Kenney devoted his adult life to the study of history, and it was this devotion combined with strong religious faith that led to the formation of the Canadian Catholic Historical Association fifty years ago.

James F. Kenney was born on 6 December 1884 in a weather-beaten farmhouse near Marysville, Ontario, a small village in Tyendinaga township, Hastings County. Situated in the south-east corner of Tyendinaga, Marysville was the focal point for the large Irish-Catholic popu-

\footnotetext{
${ }^{1}$ Public Archives of Canada, James Kenney Papers (Hereafter cited as Kenney Papers), Speech Notes, Convocation Address, University of Ottawa, June 1936. Kenney's literal translation of the Latin was 'Falsehood is old, but truth is older.' In G.S.M. Walker, Sancti Columbani Opera (Dublin Institute of Advanced Studies, 1957), this phrase is rendered: "... the error is of long standing, but truth has always stood longer." (pp. 12-13).
} 
lation who had settled the eastern portion of the township in the late 1820 's and early 1830's. Near the village, in Holy Name of Mary Church, Martin Kenney and Mary McCullough were married in February 1884 . James was their first and only child. ${ }^{2}$

Martin Kenney was born on a farm near the church in 1834, the second son of John and Anne Kenney. The Kenneys were blessed with a large family of eight daughters and four sons. All of them eventually left Tyendinaga to seek their fortunes elsewhere, except for Martin, who remained with his parents on the family farm and acquired it from them in $1873 .^{3}$ Mary McCullough was the daughter of James McCullough and Anne Macauley. She was born in 1843 at Sophiasburg in nearby Prince Edward County. Some years later her parents purchased a farm in Tyendinaga township near the village of Lonsdale, a few miles northeast of the Kenney homestead. ${ }^{4}$

There are two aspects of his family history that made a deep and lasting impression on James Kenney, the first was a strong sense of his Irish heritage and the second was fervent devotion to the Catholic faith. It is clear, too, that his parents recognized the need for and the value of a good education for their son. No effort was spared to ensure that young James developed his intellectual abilities to the fullest possible extent.

James Kenney attended a one-room schoolhouse not far from his home and successfully completed the elementary grades by the spring of 1899. Martin Kenney, anxious that his son continue his education, sold his farm and moved his small family to Belleville, Ontario, the nearest town with a high school. James subsequently attended Belleville Collegiate where he did excellent school work. He graduated in June 1903 and matriculated into the University of Toronto with pass standing in French and German and honours standing in all other subjects. ${ }^{5}$

\footnotetext{
${ }^{2}$ Holy Name of Mary Church (Marysville, Ontario), Records of Births, Marriages and Baptisms.

${ }^{3}$ Data on the Kenney family has been compiled from a number of diverse sources including Clara McFerran, "Catholic Pioneers of Tyendinaga and Neighboring Townships," Canadian Catholic Historical Association, Report 1940-1941, pp. 78-81; Public Archives of Canada, Census Returns for Tyendinaga Township for 1851, 1861, 1871 and 1881; Public Archives of Ontario, Township Land Deeps, Microfilm reel GS 4315.

${ }^{4}$ McFerran, "Catholic Pioneers", p. 81.

${ }^{5}$ Kenney Papers, “Vitae”, prepared in 1929 for Columbia University Press.
} 
In September, 1903, James Kenney journeyed to Toronto with great anticipation for what lay ahead. Leaving his parents in Belleville had been difficult for all concerned, but the Kenneys realized that a university education was an excellent opportunity for their only son. Soon after his arrival in Toronto, Kenney registered at University College, and within a few short weeks, he had adapted himself to the life of a Varsity undergraduate. The next four years as a student were happy, eventful and challenging for young Kenney. Reflecting on this experience in 1907 , he noted in his diary that "all has been ideal." 6

During Kenney's years as an undergraduate, the University of Toronto experienced rapid physical growth. New buildings were constructed, additional faculties were created and further expansion took place with the federation of Trinity College with the University. Overall enrolment increased steadily, rising from 1700 in 1903 to 2500 in 1907. Add student life flourished as never before. New residences were opened, interest in athletics increased and a variety of clubs and organizations prospered with large and active membership rolls. It was exciting to be a student at the University of Toronto and James Kenney's own personal experience was no exception.

Undoubtedly, Kenney was like many other undergraduates of his day. He led an active social life, attended dances regularly, flirted with young women in the library and had a strong interest in sports, especially fencing and boxing. At the house where he boarded, he often became embroiled in card games that distracted him from his studies. In February 1904, for instance, Kenney worried about his lack of good study habits as final examinations approached. In his diary he lamented:

Another week gone by, another week nearer that awful May. I am so far behind in my work that I really have no notion what I am going to do. However I suppose the only thing to do is to get down and plug for all I am worth. ${ }^{7}$

Plug he did, obtaining first class honours in all subjects except Greek!

Typical as he may have been, Kenney's years as a student were a challenging experience for him, an experience that had a profound

\footnotetext{
${ }^{6}$ Kenney Papers, Diary, 16 June 1907 (hereafter cited as Kenney Diary). During his years as an undergraduate at the University of Toronto, James Kenney was a faithful diarist. My account of these years is based largely on these journals.

${ }^{7}$ Kenney Diary, 21 February 1904.
} 
effect on him. By the time he graduated in 1907, his intellectual interest had developed and matured, commitment to his Catholic faith had been reinforced and, above all, he had acquired a deep and abiding love for Ireland, Irish history, language and literature.

James Kenney excelled in the study of languages, especially German, French and Latin. In his spare time, he mastered Greek and in 1906, he began to teach himself Irish. He enjoyed English Literature immensely and in the year before his graduation, he captured the University's English Essay prize with a paper in which he compared the treatment of the Arthurian legends in the works of Edmund Spencer and Alfred Tennyson. More than anything else, however, Kenney was attracted to the study of history by the chairman of the History Department, George M. Wrong, ${ }^{8}$ and his capable assistant, E.J. Kylie. ${ }^{9}$ When he reached his sophmore year, 1905-1906, Kenney decided to pursue advanced studies in the field, his goal was an academic career.

Throughout his university career, James Kenney was an active member of several student organizations. It was truly, he later wrote, "the golden age of undergraduate societies." ${ }^{10} \mathrm{He}$ belonged at one time or another to the Classical Association, the English Literature Club, the University College Literary Society, and in 1906 he was accepted as a member of the prestigious Historical Club, founded by George Wrong and described by Kenney himself as "the blue ribbon of our college life." 11

\footnotetext{
${ }^{8}$ George M. Wrong ( $1860-1948$ ) played a major role in the development of Canadian historiography. He was also an excellent teacher who took a close personal interest in the welfare of his students; Kenney was obviously no exception. On Wrong, see W.S. Wallace, "The Life and Work of George M. Wrong," Canadian Historical Review, vol. xxix, no. 3, September 1948, pp. 229-239, and Carl Berger, The Writing of Canadian History (Toronto, 1976), pp. 8-21.

${ }^{9}$ Edward J. Kylie (1880-1915) was a graduate of the University of Toronto (1901) and Oxford (1903). He was appointed to the History Department at Toronto in 1904 where he remained until his death. Kenney and Kylie were associated in the Catholic Student's Society as well as in the classroom. On Kylie, see H.J. Morgan, Canadian Men and Women of the Time (1912), p. 623; University of Toronto Roll of Service, 1914-1918 (1921), p. 81; Kenney Diary, 8 and 23 October and 6 November 1904.

${ }^{10}$ James F. Kenney, “University of Toronto, 1903-1907,'” in Torontonensis, vol. 9, 1907, p. 30.

${ }^{11}$ lbid.
} 
Kenney was also active in the Catholic Student's Society (CSS) that met from time to time in the basement of St. Basil's Church at St. Michael's College. The CSS was essentially a debating club although one of its stated objectives was "to bring the Catholic students of the city together so that they might become acquainted with one another..." 12 Kenney was invited to join shortly after arriving in Toronto in the fall of 1903 and, while he found the first meeting "rather dull", he was pleased with the opportunity to meet other young Catholic men and women. ${ }^{13}$ Eventually he served on a number of the Society's committees including Mutual Help and Religious Instruction.

Kenney also became involved in the Society's plans to erect a hall and a chapel for Catholic students in Toronto. Inspired by its founder, Father Laurence Brennan, the CSS looked into the possibility of raising funds during 1903-1904 for such a project. Unfortunately, Fr. Brennan died suddenly in June 1904 and with him went the Society's momentum. The need for a Catholic residence at the university continued to be explored by the CSS, but there was not enough sustained interest in the project nor in the Society itself to see it through to completion at that time. By October 1905, Kenney felt that the CSS was "going to pieces", ${ }^{14}$ but the Society survived long enough to occupy an important place in his life while he was at the University of Toronto.

The most dramatic and far-reaching development in James Kenney's life during his years at the University of Toronto was the emergence of a passionate interest in Ireland and all things Celtic. The awakening of his interest in his Celtic heritage can be traced to an evening in May 1906 when be came face to face with the cultural revival that was sweeping Ireland. There is little doubt that Kenney already felt a strong attachment to the land of his ancestors. This had been nurtured by the traditions prevalent in the Irish-Catholic community in which he grew up in and had been reinforced by his own extensive reading of Irish history. This enthusiasm for Ireland and its past was, however, strengthened and given focus on the evening of 17 May 1906. Douglas

\footnotetext{
${ }^{12}$ St. Michael's College Archives (Toronto, Ontario), Catholic Student's Society of Toronto, Minute Book, 25 October 1903.

${ }^{13}$ Kenney Diary, 27 October 1903.

${ }^{14}$ lbid., 23 October 1905.
} 
Hyde, President of Ireland's Gaelic League, spoke to a large Toronto audience at Massey Hall, and one of his eager listeners was James Kenney. ${ }^{15}$

The Gaelic League was founded in July 1893 by a small group of Irish scholars and folklorists including Hyde and Eoin MacNeill. The League was determined to revive and preserve Irish language, literature and history. The movement was immensely popular throughout Ireland and, by 1904 , claimed to have 600 branches and 50,000 members. While the League sought formal changes to the educational system that would permit the teaching of Irish to children, it also supported travelling teachers who held language classes, taught Irish music and dancing, history, folklore and so on. ${ }^{16}$ Douglas Hyde believed that the Celtic Renaissance, a cultural revolution, would free Ireland from England, accomplishing its goal with non-political, non-sectarian and certainly nonviolent means. The Gaelic League appealed to a large cross-section of the Irish population and was extremely popular with the Irish in North America.

When Hyde visited Toronto, he was in the midst of an extensive North American lecture tour to raise funds for the teaching of the Irish language in Ireland. He was initially sceptical about speaking in the city because it had a reputation for being fervently anti-Irish. "We are to go into Canada now," Hyde later wrote in his published diary of the trip, "amongst people who are not favorable to anything Irish." ${ }^{17}$ Sponsored by the United Irish Societies of Toronto, the charismatic leader of the League treated about 1200 people to a unique evening of enlightenment and entertainment. In a stirring speech, Hyde emphasized his one major theme: Ireland must be de-anglicized.

Kenney was already familiar with and certainly sympathetic to the aims of the Gaelic League, but nevertheless, he was moved by Hyde's appeal, in fact, he was swept away with the League's ideals. His own

\footnotetext{
15 lbid., 4 June 1906.

${ }^{16}$ Brendán S. MacAodha, "Was This a Social Revolution?”, in Seán O Tuama, The Gaelic League Idea (Dublin, 1972), pp. 20-30; Robert Hogan (ed), Dictionary of Irish Literature (Westport, 1979), pp. 302-304; M. Tierney, Eoin MacNeill, Scholar and Man of Action, 1867-1945 (Oxford, 1980), chap. 2, pp. 19-33.

${ }^{17}$ Douglas Hyde, My Trip to America, p. 157. I wish to thank Professor Daibhi 0 Croinin of University College, Galway, Ireland, for translating the Toronto portion of this book for me.
} 
feelings for Ireland were given new meaning. Kenney captured the emotional thrust of Hyde's speech in a long diary entry:

He began by giving a few moments talk in Irish, which was vociferously applauded by the few who were fortunate enough to understand it. Then he went on ... in English to tell the mission of the Gaelic League, the situation it was facing, the work it had done, the aims it entertained. Its object was the De-Anglicisation of Ireland, to make Ireland Irish, Irish in language, Irish in thought, Irish in aspirations, Irish in its past-times, Irish in its industry. The struggle was for the preservation of the national identity of the Irish people. ${ }^{18}$

The evening was a tremendous success. Hyde was delighted with the reception accorded his speech and the Irish community in the city were thrilled. By way of response, a Toronto Branch of the Gaelic League was organized by the end of May. Kenney, a willing convert to the struggle, joined immediately, started to learn Irish and immersed himself in Irish history and culture. He adopted the League's ideal as his own. About a year later, Kenney noted in his diary that "the creation of a new Irish people is a noble aim, and one which corresponds with what I hold." The Irish deserve independence from England, he continued, and

I think it is my duty to prepare myself for rendering her all possible assistance should that day ever come. Meanwhile I must help in the Gaelic movement which is giving Ireland the soul of a nation instead of that of a province. ${ }^{19}$

Douglas Hyde had cast his spell and Kenney was now a disciple. His devotion to Ireland would eventually find expression in scholarly historical research. In 1906, the nature of his future study was still unclear to him, but there was little doubt in Kenney's mind about its ultimate objective. More than anything, he wanted to contribute to a deeper understanding of Ireland's past.

Kenney's final year at the University of Toronto was easily the most satisfying not only because of his new found interest in the Irish past but also because of his scholastic achievements. He attained first

\footnotetext{
${ }^{18}$ Kenney Diary, 4 June 1906. For a contemporary newspaper account of Hyde's visit to Toronto, see The Catholic Register, 24 May 1906.

${ }^{19}$ Kenney Diary, 11 August 1907.
} 
class honours in the English and History course with the classical option and in the Latin and Modern History course. During the year he read a paper before the Classical Association on Rome and Britain, he spoke to the Historical Club on the needs of the university and he assisted in the management of the English Literature Club. In the fall of 1906, he attempted to revitalize the Catholic Student's Society by organizing a retreat for Catholic young people at the University, and in February 1907, he spoke to the Toronto Gaelic League on various poets of the Celtic Revival. ${ }^{20}$

When James Kenney graduated in June 1907, he himself recognized that an important phase in his life had come to an end. The conclusion was a happy one. "The whole thing is now over," he wrote, "I have been decorated with the academic hood, and stand up a wonderful Bachelor of Arts. Extraordinary, isn't it!"' ${ }^{21}$ Maurice Hutton, who taught Kenney at least one course in each of his four years, was impressed with his progress and later wrote:

I hardly think any student has profited more conspiculously from his University course; owing of course not merely to innate ability but to unwearied industry and application. ${ }^{22}$

Kenney's long absences from home had been a constant source of worry for his parents, but on that day in June 1907, they must have been proud of their son. He entered university in 1903 with some trepidation, unsure of himself and uncertain of his ability. Now, all of this had vanished. He had proven academic skills, he was an active participant in the practice of his faith, and the Gaelic League had given him, in his own words, "something to work for, to stand for, to regard myself as a representative of ..." 23

\section{III}

In 1907, no university in Canada offered postgraduate training in the discipline of history. Students who wished to pursue the study of history for a higher degree were forced to look to the United States or, if circumstances permitted, to universities abroad. James Kenney

\footnotetext{
${ }^{20}$ Ibid., 14 October 1906, 9 January, 5 March and 27 May 1907.

${ }^{21}$ Ibid. , 16 June 1907.

${ }^{22}$ Kenney Papers, Memo by Maurice Hutton on Kenney's application for a fellowship, n.d., probably 1907 .

${ }^{23}$ Kenney Diary, 27 May 1907.
} 
now faced this dilemma. George Wrong wanted him to study at Oxford and encouraged him "to write something on Canadian history as soon as possible," but study abroad was too expensive even to contemplate. Kenney made inquiries about the Rhodes scholarships but then decided that he was not qualified; the University of Toronto offered the Joseph Flavelle scholarship, but again, Kenney did not apply because the award was not lucrative enough. Wrong also suggested that he "beg, borrow or steal enough money to get there," but for Kenney, Oxford remained an unfulfilled dream. ${ }^{24}$

As the prospect of studying at Oxford faded from the picture, Kenney turned to the United States and applied for admission to a number of prominent graduate schools. Offers were received from Columbia University, and the universities of Chicago and Pennsylvania, but for a variety of reasons, these were rejected. The University of Wisconsin, however, offered Kenney an appointment as an assistant in European History at a rate of $\$ 250$ per annum, a salary that was later raised to $\$ 300$. It was a tempting proposition. Before making a decision, Kenney consulted with George Wrong, E.J. Kylie, James Brebner, the University of Toronto registrar, and Maurice Hutton, and the consensus of opinion was that he should accept the offer and he did. ${ }^{25}$

In the meantime, Arthur Doughty, ${ }^{26}$ the Dominion Archivist, had suggested to his friend, George Wrong, the possibility of hiring a student for the summer months. "Why do you not send down one of your men this summer," wrote Doughty, "to work up any subject you may choose from documents." ${ }^{27}$ Wrong selected Kenney and by mid-

\footnotetext{
${ }^{24}$ Ibid., 16 June 1907.

${ }^{25} \mathrm{Ibid}$.

${ }^{26}$ Arthur George Doughty (1860-1936) was born and educated in England. He came to Canada as a young man and entered the public service of the province of Quebec. Doughty devoted his leisure time to literary criticism and history and, in May 1904, he was appointed Keeper of the Records (later changed to Dominion Archivist) for the federal government in Ottawa. He published a number of books on aspects of Canadian history, co-founded the Champlain Society and edited with Adam Shortt the monumental Canada and Its Provinces (1912-1914). On Doughty, see H.J. Morgan, Canadian Men and Women of the Time (1912), p. 338; Ian Wilson, "Shortt and Doughty: The Cultural Role of the Public Archives of Canada, 1904-1935", The Canadian Archivist, vol. 2, no. 4, 1973, pp. 4-25; Carl Berger, The Writing of Canadian History (1976) pp. 26-30.

${ }^{27}$ Public Archives of Canada, Records of the Public Archives of Canada, RG 37, Volume 101, file 60-9-UT, pt. 1, A.G. Doughty to George M. Wrong, 16 March 1907. Subsequent correspondence relating to Kenney's summer job at the Archives, Wrong to Doughty, 20 May 1907, and Doughty to Wrong, 22 May 1907.
} 
June the young graduate was on his way to Ottawa and the Public Archives of Canada. ${ }^{28}$

It was a splendid arrangement for Kenney and he enjoyed the work immensely. As an introduction to archives and to Canadian history, it was an invaluable experience. He performed a number of tasks during the summer, some under the direction of the political scientist, Adam Shortt, and others in collaboration with the noted author, William D. Le Sieur. Kenney extracted and arranged documents relating to the deveiopment of responsible government in Canada, he worked on aspects of eighteenth-century French Canadian history and he assisted with the sorting and organization of the personal papers of Lord Selkirk.

With long summer evenings at his disposal, Kenney continued to improve his Irish language skills. He also established contact with members of the Ottawa Branch of the Gaelic League where he met John J. McGee, a retired senior public servant who was now devoting his energies to the restoration of the Gaelic language, John O'Gorman, a young seminarian who had helped establish the local Gaelic League, and Edward Stanton, a Post Office employee who tutored him in the Irish language. ${ }^{29}$ As Kenney recalled many years later, the summer of 1907 was a "Great adventure." 30

In mid-September James Kenney left Ottawa and, following a brief visit with his parents in Belleville, he ventured from home once again to pursue his education. He took up his duties as a graduate student

${ }^{28}$ Kenney Diary, 16 and 27 June, 15 July 1907 . Kenney was paid the princely sum of $\$ 75$ per month. The Public Archives of Canada has experienced several name changes in its 112 year history. To avoid confusion I am using the present-day name.

${ }^{29}$ John J. McGee (1845-1927) was a half-brother of Thomas D'Arcy McGee. Following a prominent career as a land surveyor, McGee was appointed Clerk of the Privy Council in 1882, a position he retained until his retirement in 1907. He devoted the remainder of his life to Irish studies (source: Annual Report of the Association of Ontario Land Surveyors, No. 43, 1928, pp. 91-95; H.J. Morgan, Canadian Men and Women (1912), pp. 765-766); John J.O'Gorman (1884-1933) was ordained in 1908 and for many years was associated with Blessed Sacrament Parish in Ottawa. O'Gorman served with distinction as a chaplain during the First World War. He also took a scholarly interest in the Irish in Canada (source: Ottawa Evening Journal, 28 April 1933); Edmund P. Stanton (1854-?) was Chief Clerk and Superintendent in charge of the Postage Stamp Branch of the Post Office Department in Ottawa in 1907 (source: Civil Service List of Canada for 1908, p. 104).

${ }^{30}$ Kenney Papers, Speech Notes, Convocation Address, University of Ottawa, June 1936. 
and instructor in the History Department at the University of Wisconsin with great enthusiasm. Under the stimulating tutelage of George C. Sellery, ${ }^{31}$ a Canadian and fellow graduate of the University of Toronto, and Dana C. Munro, ${ }^{32}$ a well-known and reputable medievalist, Kenney embarked on a serious study of the printed sources relating to early church history in Ireland. It was an appropriate topic given his intense fascination with Ireland's past and his more general interest in history and methods of historical research. By the early summer of 1908, his thesis for the Master's degree was completed and accepted by the History Department. Entitled "The Decline of the Celtic Church in Ireland, 795-1152," it marked the scholarly beginning of a life-long project for James Kenney.

Kenney seems to have enjoyed his brief stay at Wisconsin. His diary for this period is, unfortunately, restricted to a few entries and as a result not a great deal is known about his general activities. From an academic perspective, the year was an unqualified success. George Sellery later wrote that Kenney's thesis "displayed wide reading in a difficult field and constructive skill," and Frederick Jackson Turner, the great American historian, felt that Kenney showed "unusual thoroughness and intelligence in research." 33

In the spring of 1908 , Kenney was twenty-three years old and with everything falling into place, he was naturally optimistic about his future prospects. He carefully mapped out his plans and set them down in his diary. He hoped to secure a position at the Archives in Ottawa for a year or two, move his parents to Ottawa too, save what money he could and then return to Wisconsin or perhaps Columbia University

\footnotetext{
${ }^{31}$ George C. Sellery (1872-1962) was born in Kincardine, Ontario, and educated at the University of Toronto (BA, 1897) and the University of Chicago (Ph. D, 1901). Like Kenney, he was a student of George Wrong and he, too, was awarded a research fellowship at Toronto in 1897. Sellery joined the History Department at Wisconsin in 1901, attaining full professorship in 1909. He retired from active teaching, still at Wisconsin, in 1942. Sellery published a number of books on aspects of medieval history during his career (source: Who Was Who in America, vol. 4 (1968), p. 847). Sellery had a life-long reputation as a provocative and stimulating teacher who constantly challenged his students and encouraged them to work carefully and systematically (source: American Historical Review, vol. lxvii, no. 4, July 1962, p. 1186).

${ }^{32}$ Dana C. Munro (1866-1933), American born and educated, was Professor of Medieval History at Wisconsin from 1902 until 1915. He published widely in the field of medieval history (source: Who Was Who in America, vol. 1 (1943), p. 879).

${ }^{33}$ Kenney Diary, 5 April 1908.
} 
for his doctoral studies. His ambitions, goals and future tasks included the following: improvement of language skills in Irish, French and German; completion of historical training; in-depth study of Irish and Celtic lore; good public speaking; and curiously, a desire to become proficient in military science, theory and practice. ${ }^{34}$

Unfortunately for James Kenney, this springtime enthusiasm turned into a "sad and discouraging summer." 35 His elderly parents were both ill, he was forced to remain at home in Belleville and his valuable savings slowly dissipated. Less than a year before, Arthur Doughty had asked him to return to the Archives in the summer of 1908, perhaps on a permanent basis. Now, for some unknown reason, his letters went unanswered, there was no Archives appointment and his hopes were dashed. During the summer the University of Wisconsin offered to renew his contract, a position that he could combine with his own advanced studies, but Kenney hesitated in anticipation of employment in Ottawa, and the offer was withdrawn before he could accept.

Gloomy and discouraged, Kenney approached George Wrong for assistance. He urged Kenney to apply for the Alexander Mackenzie Fellowship in Canadian History tenable at the University of Toronto and valued at \$375. With Wrong's strong personal support, Kenney's application was successful and by November 1908, he was back on familiar ground in Toronto. Under Wrong's supervision and direction, he began research for a projected history of the city of Toronto.

This sudden change of circumstances was an excellent antidote for James Kenney's troubles. The income from the fellowship allowed him to continue his studies and to support his parents, he was close once again to Dympna Byrne, ${ }^{36}$ the young woman he would eventually marry, he renewed his contacts with the Gaelic League and with student societies at the University. He rekindled his association with the Catholic students of the University in 1908 when the Catholic club and chapel project was revived. With this level of involvement in extra-curricular

\footnotetext{
35 Ibid. , 2 September 1908.

${ }^{36}$ Dympna Byrne (1885-1944) was born in Fergus, Ontario. She and James Kenney first met at a Toronto Gaelic League meeting in 1907. They were married at St. Basil's Church (Toronto) in September 1916. Dympna Byrne was noted for her interest in art, especially for her work in water colours and in china painting (source: Kenney Diary, 5 March 1907; Toronto Star, 23 September 1916; Toronto Telegram, 2 June 1944).
} 
activities, it is not surprising that Kenney's history of Toronto languished after thirty pages and was never completed. The study of early medieval Ireland was far more important to him and, as his diary shows, he had. little enthusiasm for early Toronto!

In April 1909, Kenney received some very good news. Columbia University in New York City appointed him a Fellow in Medieval History for the academic year 1909-1910. He registered at the end of September in the Department of Political Science and, while he spent less than one year at Columbia, it was without doubt the most important twelve months in his life in terms of intellectual development. His major field of study was medieval history and he took minor courses in American history and in Celtic languages under the direction of several scholars, the most prominent being James T. Shotwell and John L. Gerig. ${ }^{37}$

The main attraction for Kenney at Columbia was James Shotwell, an expatriate Canadian who, like Kenney, was a graduate of the University of Toronto and a former student of George Wrong. Shotwell had a tremendous love and devotion for the study of the middle ages, especially for the medieval church. He encouraged his students to use original documents and sources for research purposes. In Kenney's case, Shotwell urged him to continue the research that he had begun at Wisconsin two years earlier on Irish history, a project that would slowly

\footnotetext{
37 James T. Shotwell (1874-1965) was born and educated in Canada at the University of Toronto where he studied history with George Wrong and at Columbia University. He taught history and later international relations at Columbia from 1900 until 1942. Shotwell was a constant source of encouragement to Kenney during the latter's long years of labour on his thesis. Kenney regarded him as the single most influential historian that he came into contact with during his years as a student (source: Shotwell, Autobiography (1965), pp. 38-55; Who Was Who in America, vol. 4 (1968), p. 860; see also Kenney's comment on Shotwell in the former's Sources for the Early History of Ireland (1929), p. x). John L. Gerig (1878-1957) was American born and educated. He joined the staff of Columbia in 1906 and taught Romance Languages and Celtic until the 1940's. Gerig was active in a number of associations devoted to language studies and philology and in his lifetime earned a reputation as a pre-eminent Celtic scholar (source: Who Was Who in America, vol. 3 (1960), p. 319). Kenney studied Old and Middle Irish with Gerig and in his preface to Sources states that he appealed to him "repeatedly for information and advice, and always with success." (Sources, p. $x$ ).
} 
expand and evolve until it became a comprehensive and critical analysis of all printed ecclesiastical sources relating to Ireland to the twelfth century. ${ }^{38}$

It had been a marvellous year in New York. Kenney later told a young colleague of his that he "had not discovered what historical study was until he went to Columbia." ${ }^{39}$ Under Shotwell he had learned to study original documents and sources with a critical eye and he acquired the training that would equip him for his long study of early Irish history. From Shotwell's perspective, Kenney's year at Columbia was "a year of solid work exhibiting both high ideal of scholarship and keen insight and remarkable powers of application and concentration." His doctoral thesis, Shotwell predicted, would be "a very important contribution to European history." 40

After the successful completion of his exams in May 1910, Kenney remained in New York for three or four months in order to continue his thesis research in the excellent libraries at Columbia and at the Union Theological Seminary. He returned to Toronto in September to teach Latin and History at St. Michael's College. According to the college yearbook, he was a conscientious instructor, but his contract was not renewed in June 1911. ${ }^{41}$ From the spring of 1911 until May 1912 , Kenney worked at a variety of jobs but he does not seem to have had any regular employment. He organized and arranged the private papers of Edward Blake ${ }^{42}$ on behalf of the University of Toronto Library, he conducted some research for James Shotwell for a book of documents that he was preparing and he applied unsuccessfully for a teaching position in at least one Canadian university. While in Toronto, he resumed his connection with the Gaelic League, but most of his time was spent at home. With nothing else to do and his future bleak, James Kenney returned to Belleville and waited.

\footnotetext{
${ }^{38}$ Kenney's work in early Irish history and his reputation in that field are fully explored in an article of mine to be published in Peritia, the journal of the Medieval Academy of Ireland, in 1984.

${ }^{39}$ Arthur Lower, My First Seventy-five Years (Toronto, 1967), p. 132.

${ }^{40}$ Kenney Papers, James T. Shotwell, Letter of Recommendation for James F. Kenney, 6 June 1911.

${ }^{41}$ Rev. R.J. Scollard, Archivist, St. Michael's College, to the author, 9 August 1982. The record of the Treasurer's Office show that Kenney was paid $\$ 990$ for his teaching; St. Michael's College, Yearbook, 1910-1911, p. 26.

${ }^{42}$ Edward Blake (1833-1912). Former leader of the Liberal party, 1878-1887, and member of the British House of Commons, 1892-1907. Blake's son-in-law was George Wrong.
} 
When James Kenney left the teaching staff of St. Michael's College in the spring of 1911, he was twenty-six years old. His mother had passed away in January leaving him responsible for the care of his father whose health was uncertain. With his thesis research only partially completed, the possibility of securing an academic appointment appeared non-existent. Teaching, however, was not the only occupation that appealed to Kenney. He was trained to be an historian and he wanted to use the skills he had learned. With this in mind, he applied to the federal Civil Service Commission in April 1911 hoping to obtain a position in the Public Archives in Ottawa.

In support of his application, George Wrong penned an enthusiastic note to Arthur Doughty, emphasizing that Kenney was "a real scholar and can write well," adding that he was "a trustworthy and satisfactory man." ${ }^{43}$ Permanent positions were few in number and there were no openings. Wrong interceded again and prodded Doughty with another letter in August 1911, but it was all to no avail. Finally, in May 1912, as a result of a government reorganization of the Archives, James Kenney joined the staff and embarked on a career in the Public Archives of Canada that would span thirty-four years. ${ }^{44}$

The Archives had been established in $\mathbf{1 8 7 2}$ and gradually, under the careful leadership of Douglas Brymner, private manuscripts and records relating to Canada's past were collected and preserved. Brymner retired in 1902 and his successor, Arthur Doughty, steered the institution into a new 'golden age.' After decades of neglect and inadequate facilities, a new Archives building was constructed on Sussex Street and opened in 1906. Doughty was a prodigious collector of manuscripts, books, paintings and museum objects on all aspects of Canadian history and in a few short years, the Archives was filled with the treasures of the country's heritage. In 1912, a new Archives Act was proclaimed; as a result, staff were added and archival activity expanded in Canada and abroad.

Kenney was first assigned to the manuscript room where he classed and arranged manuscript collections. He also assisted with the editorial

\footnotetext{
43 PAC, RG 37, vol. 101, file 60-9-UT (part 3), Wrong to Doughty, 5 April 1911.

44 PAC, Records of the Public Service Commission, Record Group 32, series C 2, vol. 365, James F. Kenney - Personnel File, Classification Card, 10 January 1928, provides details about Kenney's appointment to the Archives in 1912.
} 
work on the voluminous annual reports and other publications produced by the Public Archives and in 1917, he assumed sole responsibility for this task. In 1922, he was given the title of Chief, Editing and Research Division, and four years later, he was elevated to the position of Director, Historical Research and Publicity, a title he retained until his death in $1946 .{ }^{45}$

For many years, Kenney was also responsible for the Archives' growing collection of paintings, prints and drawings. In 1919 he undertook the preparation of a detailed catalogue consisting of descriptions of 771 portraits of persons who had some connection or involvement with Canadian history. The Catalogue of Pictures in the Public Archives of Canada was not published until 1925 and a projected second volume never appeared. ${ }^{46}$ Kenney was a keen believer in the use of pictorial material to illustrate the Canadian past, and in his introduction to the Catalogue, he made these observations:

Of the value of the pictorial record for historical purposes there is now a general high appreciation. We live in an age when the pictorial presentation of fact or fiction has had an extraordinary revival and development. In the field of history this new interest shows itself in the use of exhibits, of lantern slides, and even of moving pictures. The collection in the Public Archives is being drawn on more and more by scholars for material both for the illustrations in their books and for the lanternslides that supplement their lectures. ${ }^{47}$

As Director of Historical Research and Publicity, Kenney was responsible for assisting researchers and scholars who used the Archives; he was also responsible for publicizing Archives' events such as exhibitions.

In spite of a very active daily routine at the Archives, James Kenney found time to pursue other scholarly endeavours. In 1917 he prepared an article on Catholic education in Canada for the Encyclopedia Americana, and in 1919, he drew upon his thesis research for a lengthy analysis of the legend of St. Brendan that was read before the Royal

\footnotetext{
45 lbid.

${ }^{46}$ James F. Kenney, Catalogue of Pictures (Part 1) (Ottawa, 1925). The catalogue included not only paintings, but also drawings and prints; Kenney wrote the introduction as well as providing explanatory notes for each entry.

${ }^{47}$ lbid., pp. xi-xii.
} 
Society of Canada in May 1920 by Arthur Doughty. ${ }^{48}$ The formation of the Canadian Historical Association in 1922 also provided Kenney with another outlet for his energy and talents as an editor. Between 1922 and 1924 he was editor of the annual reports of the new association. And in 1925 he served as the treasurer of the Ottawa-based Canadian Authors Association. ${ }^{49}$

Foremost in Kenney's mind, however, was his doctoral thesis for Columbia University. A secure job and a regular income gave him the means to carry on his research in a manner not possible before 1912 . He was now able to purchase books and journals that were generally not available in Ottawa, and on several occasions, he travelled to New York to consult with James Shotwell and John Gerig and to make use of the library collections at Columbia. As early as February 1916, Kuno Meyer, the great Celtic scholar and philologist, read a portion of Kenney's incomplete thesis and was deeply impressed with the research and scholarship. ${ }^{50}$ The work continued in fits and starts and not until November 1926 did Kenney complete his manuscript, the culmination of nearly twenty years's labour!

In February 1927, he applied to Columbia University for re-instatement as a doctoral candidate. Publication of the manuscript was assured by Austin Evans, one of Kenney's advisors and editor of the University's Records of Civilization series. Once his status was clarified, an examination date was set for 22 April. Kenney was successful; in a diary kept at the time, he noted very simply: "Passed exam. Not entirely satisfied myself, but did well." ${ }^{51}$ On the following morning, after an evening of dinner and dancing, Kenney and his wife, Dympna, sailed from New York aboard the S.S. Celtic bound for Ireland. The trip was a combination of business and pleasure and would last five months - it was James Kenney's first and only visit to Ireland.

\footnotetext{
${ }^{48}$ Arthur Doughty presented the paper on St. Brendan to the Royal Society of Canada because Kenney was not yet a member of the Society and only members could read papers at the annual meetings. Kenney was elected to the RSC in 1934. This paper was published as "The Legend of St. Brendan," Royal Society of Canada, Transactions, Section II, 1920, pp. 51-71

49 Canadian Who's Who, Volume III, p. 368; Canadian Historical Association, Annual Reports, 1922-1925.

${ }^{50}$ Kenney Papers, Kenney to Kuno Meyer, 18 February 1916; Meyer to Shotwell, 6 December 1916 (original in Kenney Papers).

${ }^{51}$ Kenney Diary, 23 April 1927.
} 
The main purpose of Kenney's extended trip to Ireland during the spring and summer of 1927 was to investigate archival records of Canadian interest held either in Irish repositories or in private hands. The copying of documents relating to Canada in England and in France had been a long tradition for the Public Archives, but this was the first time that a senior member of the staff had visited Ireland to seek out documents.

A week after his arrival in Dublin, Kenney felt that the prospects of a good find were "not very promising," ${ }^{52}$ but within days, at the Public Record Office (PRO) in Belfast, he made a remarkable discovery. In 1926 the papers of one Arthur Dobbs were donated to the PRO and amongst the collection were the journals, letters and memoranda of Henry Kelsey, explorer, mariner and long-time employee of the Hudson's Bay Company who firmly established the Company in North America through his explorations in Western Canada. ${ }^{53}$ It was a most significant discovery and Kenney was thrilled. He immediately made arrangements to have the material copied and forwarded to Ottawa. During the course of his stay in Ireland, other papers were identified, copied and sent to the Public Archives including documents relating to James Wolfe and various custom house records. Important contacts were established with Irish archivists and librarians and Kenney came away with a sound knowledge of documentary sources in Ireland relating to Canada.

But Kenney's visit to Ireland was not confined solely to the business of the Public Archives of Canada. It was his first trip abroad and his five month stay provided him with an excellent opportunity to soak up the Irish atmosphere and to see for himself some of the many historic sites connected with the early history of the country that he knew so well. He told Austin Evans at Columbia that he was having "a most enjoyable time. I am getting an excellent ... training in the topographical and archaeological background of Irish history." 54 It also gave him the long-awaited opportunity to meet some of the Irish scholars that he

\footnotetext{
52 PAC, RG 37, vol. 103, file “James F. Kenney”, Kenney to Doughty, 7 May 1927.

${ }^{53}$ On Kenney's discovery of the Kelsey papers, see ibid, Kenney to Doughty, 1 and 15 June 1927; Arthur Doughty and Chester Martin, The Kelsey Papers (Ottawa, 1929), especially the introduction, pp. ix-x; and J.F. Kenney, "The Career of Henry Kelsey," Royal Society of Canada, Transactions, Section II, 1929, pp. 37-71.

${ }^{54}$ Kenney Papers, Kenney to Evans, 24 June 1927.
} 
emulated and admired from afar during the long years of his thesis research including Richard I. Best, National Librarian of Ireland, Robert A.S. Macalister and Eoin MacNeill; for the first time, he met Paul Grosjean, a young Celtic scholar, who befriended Kenney and assisted him immensely with the final revision of his thesis. ${ }^{55}$ Time flew by quickly for the Kenneys. They completed their stay with a three week holiday in London and returned home in mid-September.

While Kenney was enjoying Ireland, Austin Evans and Columbia University Press were struggling with the difficult and tedious task of typesetting his huge manuscript. Hundreds of footnotes, detailed bibliographies and the use of several languages in the text resulted in a long series of problems. As galleys were produced, Kenney insisted that they be sent to him in Ireland. He made dozens of corrections and additions. Others who read the galleys, such as Paul Grosjean, also made suggestions that created lengthy delays. Kenney was a meticulous scholar who insisted on perfection in his manuscript. Relations between him and Columbia University Press often became strained and on several occasions, Austin Evans was called upon to mediate. Finally, in December 1929, after $21 / 2$ years with the printer, The Sources for the Early Hystory of Ireland (Volume 1: Ecclesiastical) was published and James Kenney's reputation as an Irish scholar was assured. ${ }^{56}$

Sources had an immediate impact on the scholarly world. Reviewers in Ireland, in England and in the United Stated praised the book as one of the finest contributions to early Irish history. "It is a monument of which any scholar should be proud," wrote James Shotwell to his former student. ${ }^{57}$ In the preface to his book, Kenney stated that it was "designed to serve as an introduction and guide to the study of the written sources for the early history of Ireland" for the period prior to the Anglo-Norman invasions to about 1170 A.D. The book was a combination of bibliography, commentary and evaluation of all the significant ecclesiastical sources "illustrative of old Irish life and

\footnotetext{
${ }^{55}$ Kenney Diary, 5-6 May, 21 and 24 July 1927; Kenney Papers, Kenney to Grosjean, 11 May 1928.

${ }^{56}$ The full title of Kenney's book is The Sources for the Early History of Ireland, An Introduction and Guide ... in Two Volumes, Volume One: Ecclesiastical (Columbia University Press, New York, 1929). The book was in a series sponsored by the Press called "Records of Civilization: Sources and Studies." Sources has been reprinted twice since 1929, in 1966 and again in 1979.

${ }^{57}$ Kenney Papers, Shotwell to Kenney, 21 January 1930.
} 
civilization." ${ }^{58}$ Over 650 entries were discussed in detail and the book featured a long chapter on "History in Ireland", over 200 footnotes and a number of bibliographies consisting of hundreds, if not thousands, of books and articles. Sources was a massive study of nearly 900 pages that would have a profound impact on the course of Irish studies and historiography.

Eoin MacNeill referred to Sources as "a grand work" and "a masterly volume." 59 Book reviews in dozens of scholarly journals praised Kenney's archievement, for example, the reviewer for the Irish Ecclesiastical Record wrote that:

It is hard to estimate the worth of such a work as this. The advantage it confers on the student of today can only be properly appreciated by those who have worked without it in the past. It should act as a powerful stimulus to investigation... It is sufficient to say that Dr. Kenney's great work is indispensable to all serious students of Irish history... ${ }^{60}$

Richard Best, who had seen some of the galleys of Sources when Kenney was in Ireland in 1927, was not disappointed with the final outcome. "It is a great work," he told Kenney in February 1930, "truly monumental, quite the biggest thing that has been done in Irish studies for many a year. You have laid all students of Irish history under a heavy obligation." ${ }^{61}$

The book that took twenty years to research and write brought James Kenney some well-deserved recognition including honorary degrees from the University of Ottawa and the National University of Ireland, election to the Royal Society of Canada and from the Irish Republic, the Aonach Tailteann Award for the best book in Irish studies published during the years 1928-1932.

The publication of Kenney's Sources was also one factor in a series of events that led to the creation of the Canadian Catholic Historical Association in 1933.

\footnotetext{
${ }^{58}$ Kenney, Sources, Preface, p. ix.

${ }^{59}$ Kenney Papers, MacNeill to Kenney, 17 February 1930, and MacNeill's comments as quoted in the Gaelic American, 12 April 1930, p. 2.

${ }^{60}$ Irish Ecclesiastical Record, May 1930, pp. 554-555.

${ }^{61}$ Kenney Papers, Dr. Richard I. Best to Kenney, 25 February 1930.
} 
The American Catholic Historical Association (ACHA) was organized at Cleveland, Ohio, in December 1919, in the words of one of its founders, "to create and to sustain a broader and deeper interest in the problems which confront the historians of the Catholic Church." 62 By means of a quarterly journal, The Catholic Historical Review and annual meetings held in conjunction with other learned societies, the ACHA promoted study and research in the general history of the Catholic Church throughout the world and, by doing so, the founders hoped to stimulate scholarship among Catholics and to make the history of the church better known. The Association's offices, established at the Catholic University of America in Washington, D.C., also served as a clearing house for information on published and unpublished sources relating to Catholic history.

It is not known whether James Kenney attended the initial meeting of the ACHA in 1919, but he was definitely interested in the objectives of the society and seven weeks later, he joined the Association. In March 1924, the Rev. Peter Guilday, ${ }^{63}$ Secretary of the ACHA, approached Kenney about giving a paper at the December meetings in Philadelphia. Kenney agreed and presented a brief paper in which he analyzed the various medieval texts relating to the life of the Irish saint, Columcille. ${ }^{64}$ Kenney and Guilday met for the first time, a friendship developed that would have a direct bearing on the establishment and the character of the Canadian Catholic Historical Association

\footnotetext{
${ }^{62}$ American Catholic Historical Association, A Retrospect of Fifteen Years, 1919 1934 (1935), p. 2; see also Rev. Peter Guilday, "The American Catholic Historical Association," Catholic Historical Review, vol. vi, no. 1, April 1920, pp. 3-14.

${ }^{63}$ Peter Guilday (1884-1947) was born in Chester, Pennsylvania, of Irish parentage. Ordained in July 1909, Guilday soon after proceeded to Belgium where he studied for his doctorate at the University of Louvain. Following his graduation in 1914, he returned to the Catholic University of America. In 1915, he launched the Catholic Historical Review, and was one of the Prime movers behind the formation of the ACHA in 1919. Guilday inaugurated courses in American Catholic history at the university level and through his numerous publications, he helped to stimulate interest in Catholic history in the United States. Source: Matthew Hoehn (ed), Catholic Authors, Contemporary Biographical Sketches, 1930-1947 (St. Martin's Abbey, 1948), pp. 298-299; New Catholic Encyclopedia (1967), vol. vi, pp. 844-845.

64 The paper which Kenney presented to the ACHA in 1924 was later published as "The Earliest Life of St. Columcille," Catholic Historical Review, vol. xi, no. 4, January 1926, pp. 636-644.
} 
(CCHA) eight years later. Both men were of Irish extraction, they were the same age and, above all, they shared an enthusiasm and passion for research and history.

By 1929, Kenney was well acquainted with key members of the ACHA. They, too, eagerly awaited publication of The Sources for the Early History of Ireland. When the book appeared, Guilday's reaction was similar to that of most other scholars and academics, he was simply overwhelmed with Kenney's achievement, " "...the most excellent work of scholarly research in the field..." he told his friend. ${ }^{65}$ Bishop Thomas J. Shahan, Rector of the Catholic University of America and a medieval scholar himself, was jubilant and wrote a long, laudatory review of the book for the Catholic Historical Review. ${ }^{66}$ With no hesitation, Guilday asked Kenney to appear on the programme of the 1930 annual conference and to give a paper on Irish history as a field of study for American scholars. ${ }^{67}$

While attending these meetings which were held in Boston during Christmas week, Kenney allowed his name to stand for election to the ACHA executive. He was elected Vice-President for 1931 and automatically succeeded to the Presidency in January 1932. His duties as a member of the executive, at least in 1931, were not onerous, but his name and reputation contributed a certain amount of prestige to the Association. In 1931, the annual meetings of the ACHA took place in Minneapolis and once again, Kenney was asked to present a paper. The theme of the conference was the Catholic Church in contemporary Europe, 1919-1931, and while this was a period far removed from his medieval interests, Kenney delivered a thoughtful paper on the church

\footnotetext{
${ }^{65}$ Catholic University of America (Washington, D.C.), American Catholic Historical Association Archives (Hereafter cited as CUA/ACHA), Correspondence - 1930, Guilday to Kenney, 11 February 1930.

${ }^{66}$ Bishop Thomas J. Shahan (1857-1932) taught Church History and Patrology at CUA from 1891 until 1909 when he assumed the rectorship of the University, a position he held until 1928. He was a strong supporter of the ACHA. Shahan published several books on the middle ages and early Irish history. Source: New Catholic Encyclopedia (1967), vol. xiii, pp. 156-157. Shahan's long review of Kenney's book was published as "Ireland's Record of Civilization," Catholic Historical Review, vol. xvii, no. 2, July 1931, pp. 175-182.

${ }^{67}$ Kenney's 1930 paper delivered before the ACHA's Boston meeting was published as "Early Irish History as a Field of Research by American Students," Catholic Historical Review, vol. xvii, no. 1, April 1931, pp. 1-9.
} 
in Ireland. ${ }^{68} \mathrm{He}$ also assumed the presidency of the Association, no small achievement for a man who was neither an American nor an academic in the strict sense of the word. It was, however, appropriate recognition of his superb contribution to early Irish history.

As the chief executive officer of the ACHA, Kenney's major task was the planning, in co-operation with Peter Guilday, of the Association's 1932 conference to be held in Toronto, the first time that the American learned societies had met outside of the United States. Bishop Shahan suggested that a theme be chosen that would fit the milieu and 'The Catholic Church in Canada' was adopted.

Both Kenney and Guilday felt that the programme should consist of eight or ten papers that collectively would provide a summary of the sources available for researchers as well as an overview of the main trends in Canadian Catholic history. Kenney spent three weeks in Toronto during January 1932 and while organizing the conference was not difficult, selecting participants and matching them with desired topics was frustrating and time-consuming. A balance was hard to achieve. It was important, Kenney felt, that major topics such as sectionalism and separate schools be included and that participants be representative of English and French speaking Canada. Several of those approached to give papers declined, others withdrew at inopportune times, and still others were unable to attend the meetings to present their own papers. ${ }^{69}$ In the end, the programme did not focus exclusively on Canadian Catholic history, but this could not be avoided, yet the conference featured presentations on a number of areas including the French Regime, the American Revolution, the Glengarry Catholics and

\footnotetext{
${ }^{68}$ This paper was published under the title, "The Catholic Church in Contemporary Ireland," Catholic Historical Review, vol. xviii, no. 2, July 1932, pp. 159-176.

${ }^{69}$ On planning the 1932 Toronto conference, CUA/ACHA, Correspondence - 1932, Kenney to Guilday, 3 January 1932, 4 and 17 February 1932; Kenney Papers, Kenney to Senator Charles Murphy, 11 October 1932.
} 
in his presidential address, Kenney delivered a long paper on the relations between Church and State in Canada since 1763. ${ }^{70}$

If nothing else, the 13th annual meeting of the ACHA emphasized the underdeveloped state of Canadian Catholic historiography. It also revealed the tremendous potential for those interested in researching and writing about the history of the Church in Canada. This was not lost on the participants, and throughout the conference, important discussions were taking place on the question of forming a Canadian version of the American Catholic Historical Association. On the first evening of the conference, Rev. Michael Cline, Chairman of the Local Arrangements Committee, welcomed the delegates with a short speech in which he broached the subject of an historical association for Catholics in Canada. "We feel that Canada greatly needs the awakening breath of these historians," he told the delegates, "to bring to light the silent and neglected records of her adventurous and spacious past. It will be the duty of all of us here in Toronto to stimulate and if possible to add to the prestige of this great occasion." ${ }^{71}$ The concept of such a society had apparently been brewing for some time, although Kenney had often felt that Canadian Catholics were "extraordinarily indifferent to history." 72 Now the evidence suggested otherwise. The enthusiastic response to the meetings in Toronto was enough proof for James Kenney and others that the time was right to test the waters.

\footnotetext{
${ }^{70}$ The final programme for 1932 feature the following participants and papers: James Kenney, "Relations Between Church and State in Canada Since the Cession of 1763'" (Presidential Address); Rev. Edward J. Byrne, "The Catholic Question in Presidential Elections in the United States"; A.G. Doughty, "Sources for the History of the Catholic Church in the Public Archives of Canada"; Rev. G.J. Garraghan, "The Ecclesiastical Rule of Old Quebec in Mid-America"; Paul Kiniery, "Efforts Made by Religious Bodies to Maintain Peace in Colonial New York"; Rev. Ewen J. MacDonald, "Father Roderick Macdonnell, Missionary at St. Regis and the Glengary Catholics"; John J. Meng, "The Place of Canada in French Diplomacy of the American Revolution"; Pierre-Georges Roy, "La Paroisse et l'Habitant canadien sous le Régime français"; Rev. Edward Ryan, "The Oxford Movement in the United States"; Rev. Samuel Knox Wilson, "Bishop Briand of Quebec and the American Revolution". Many of these papers were subsequently published in the Catholic Historical Review. The Review also has a lengthy description of the 1932 meeting in vol. xix, no. 1, April 1933, pp. 50-63.

${ }^{71}$ Father Cline's remarks are quoted from the Catholic Historical Review, vol. xix, no. 1, April 1933, p. 53.

72 CUA/ACHA, Correspondence - 1932, Kenney to Miss Lyon, 16 February 1932. Kenney made these rather pessimistic remarks long before the successful meeting in Toronto changed his mind about Catholic history in Canada.
} 
Other factors were at work as well. As the Rev. Michael Sheehan pointed out twenty years ago, the birth and subsequent growth of the Canadian Catholic Historical Association was only one manifestation of a vast movement that witnessed a remarkable resurgence of interest in the history of the Church beginning in the latter decades of the nineteenth century. ${ }^{73}$ The establishment of the ACHA in 1919 is a good example of the general trend toward interest in historical matters that was emerging within the church and amongst its members.

James Kenney and his supporters were also influenced by another broad intellectual movement in Canada when they decided that the time had arrived for a Canadian association devoted to Catholic history. The 1920's had witnessed a "renaissance" in Canadian historical studies that was based almost exclusively on the vast and unused collections of historical records at the Public Archives in Ottawa. The Archives at this time, in the words of historian Carl Berger, "became a vital scholarly centre ... not only a place for research but also a clearing house for the discussion of work in progress, mutual criticism, and education in the techniques of critical, documentary history." ${ }^{74}$ Kenney was not only aware of this trend, he was part of it both as a member of the Public Archives and as a researcher and scholar.

Renewed interest in Catholic history was a natural outcome of this movement in the 1920's. "One pregnant result of this renaissance," wrote the Rev. Hugh J. Somers in 1931, "is the increased interest being shown in the history of the Catholic Church in all the Canadian provinces." ${ }^{75}$ It was in this milieu, in this intellectual environment, that James Kenney proposed the formation of the Canadian Catholic Historical Association.

On 30 December 1932, the final evening of the Toronto conference, Kenney hosted a dinner party for 40 to 50 guests at the Alexandra Palace Hotel. He spoke to his friends and colleagues of his intention to organize a Catholic history association in Canada. He was warmly

\footnotetext{
${ }^{73}$ Rev. Michael Sheehan, "Considerations on the Ends of the Canadian Catholic Historical Association," Canadian Catholic Historical Association, Report 1963, pp. 22-31.

${ }^{74}$ Carl Berger, The Writing of Canadian History (1976), pp. 29-30.

${ }^{75}$ Rev. Hugh J. Somers, The Life and Times of the Hon. and Rt. Rev. Alexander Macdonnell, First Bishop of Upper Canada, 1762-1840 (Washington, 1931), Preface, p. vii.
} 
supported by several speakers, especially by the guest of honour, Peter Guilday, who provided the spark of encouragement with a powerful address in which he appealed to all those present to support Kenney's project. Guilday's appeal was later described by a member of the. audience as eloquent and electrifying. "Great enthusiasm prevailed," wrote Brother Alfred, "and everybody present felt that with such an auspicious beginning, success was already assured." ${ }^{76}$ When all the speech-making was finished, a small committee was organized to explore the possibility of creating such an association; its members were James Kenney, Chief Justice F.R. Latchford and the Rev. J.B. O'Reilly. ${ }^{77}$

The provisional committee met in Toronto on a number of occasions during the early months of 1933 to discuss the organization of the proposed association. Encouraged by the positive response it had received from Catholics interested in history, the committee called a final meeting at the Jesuit Seminary of Philosophy on 5 March 1933. ${ }^{78}$ At first, not all of the 14 in attendance agreed that a Canadian Catholic historical association should be formed, but eventually the doubtful were won over. ${ }^{79}$ The task of completing the structure of the new association was assigned to three committees, Constitution and By-Laws, Organization, and Local Arrangements. Kenney and his fellow founders decided that the new Canadian Catholic Historical Association would be modelled on the ACHA, in fact, in the early stages of discussion, it had been suggested that a branch society of the American association be formed. This idea was quickly put to rest by Peter Guilday himself who felt that the CCHA should be autonomous from the ACHA and strictly Canadian. ${ }^{80}$

Kenney was anxious to complete the organization of the Association. A draft constitution, based on that of the ACHA, was finished in early May and sent to all members of the hierarchy in Canada for

\footnotetext{
${ }^{76}$ CCHA, Bulletin, no. 1, 1948, p. 7.

${ }^{77}$ Canadian Catholic Historical Association, Report 1933-1934, Secretary's Report, p. 6; Ottawa Citizen, 4 January 1933.

${ }^{78}$ CUA/ACHA, Correspondence - 1933, Kenney to Guilday, 1 and 10 March 1933.

${ }^{79}$ CUA, Peter Guilday Papers, File 46, 1932. Press Release concerning the establishment of the CCHA, n.d., circa January 1933; CUA/ACHA, Correspondence - 1933, Kenney to Guilday, 10 March 1933; John J.K. O'Farrell, "Canadian Catholic Historical Association's Fortieth Anniversary: A Retrospective View," CCHA, Study Session 1973, pp. 61-64.

${ }^{80}$ CUA/ACHA, Correspondence - 1933, Guilday to Kenney, undated (draft telegram), circa March 1933.
} 
approval. Finally, on 3 June 1933, the first formal meeting of the CCHA took place at the Royal York Hotel in Toronto with about 75 persons in attendance. The constitution was adopted and the Association's first executive council was elected, including Judge Latchford as President and James Kenney as Secretary. The foundations had been laid, Kenney later reported, "for the real work of the Association in the promotion of historical studies and of interest in the history of the Church..." 81

The CCHA also adopted a number of objectives at its first meeting: to encourage historical research and public interest in the field of Catholic history; to promote the preservation of historical sites and buildings, documents, relics and other significant heirlooms of the past; and to publish historical studies and documents as circumstances permitted. The founders felt strongly that the new association should aim to unite Canadian workers in Catholic history and to assist them in presenting the results of their investigations to the public, to assist historical study and teaching with bibliographies and catalogues of archival sources, to create a bureau of information to answer inquiries of an historical nature, and to assist Catholic educational institutions in raising the standards of history teaching.

The Canadian Catholic Historical Association was an ambitious undertaking, but no time was lost, and shortly after the June meeting, two committees were appointed, one on archives and a second on bibliography. One of the first actions of the Executive Council was the creation of an Archives Committee under the chairmanship of the Rev. Hugh J. Somers. ${ }^{82}$ A survey of national and international ecclesiastical and secular archives was planned in order to identify collections bearing on Catholic history in Canada. Somers hoped that a guide could be published showing the name, location, extent and nature of these archival collections. The Association also appointed a committee to compile a bibliography of all printed sources relating to general Catholic history and a second bibliography on Canadian Catholic history. Both of these projects were overly ambitious given the limited resources of the Association, and no concrete results were achieved for a long time.

\footnotetext{
${ }^{81}$ CCHA, Report 1933-1934, Secretary's Report, p. 6; Canadian Annual Review for 1933, p. 554.

${ }^{82}$ St. Paul University (Ottawa), Canadian Catholic Historical Association Archives (hereafter cited as SPU/CCHA), CCHA Bulletin No. 1, 31 October 1933; Minutes of the Executive Council, CCHA, 11 November 1933.
} 
The Executive Council had two very important tasks to -carry out in the latter months of 1933, the formation of a French language section of the Association, and of equal importance, the planning of the CCHA's first annual meeting for the spring of 1934.

From the very outset, in March 1933, James Kenney envisioned a national historical association comprising members of the two main language groups in the Canadian Catholic Church. In other words, he wanted the Association to have representation from the province of Quebec. Provision for a dual society was included in the constitution approved at the founding meeting in June; the relevant section read:

At the time of any annual meeting the members of the Association who use the French language may form a separate section, and thereafter the Association shall consist of two sections, the one English, the other French (section 8). ${ }^{83}$

The autonomy of each section would be recognized, but at the same time, they would be united, in Kenney's words, "for the common purpose of the promotion of Catholic history." ${ }^{84}$

The Executive Council of the CCHA met for the second time on 11 November 1933. Kenney was present, as well as Judge Latchford, Senator William McGuire, Miss Frances Boland, the Rev. Edward Kelly and the Rev. J.B. O'Reilly. On a resolution moved by Kenney and seconded by McGuire, a special committee was established to look into "the desirability and the practicability of forming, at the annual meeting to be held in the spring of 1934, a French section of the Association." 85 The committee was co-chaired by Kenney and L'Abbé Ivanhoë Caron. ${ }^{86}$ Caron, assistant archivist for the province of Quebec, had been an enthusiastic supporter of the CCHA and a French section since the spring of 1933 . To Kenney he wrote:

\footnotetext{
${ }^{83}$ The first constitution of the CCHA is reprinted as an appendix to the 1933-1934 Report of the Association, pp. 93-95.

${ }^{84}$ SPU/CCHA, Kenney to Latchford, 17 Avril 1934.

${ }^{85}$ Ibid., Minutes of the Executive Council, CCHA, II November 1933.

${ }^{86}$ L'Abbé Ivanhoë Caron (1875-1941) was born at L'Islet, Quebec, and received his education in Quebec City and in Rome. He was ordained in 1900. In 1923 he joined the provincial archives of Quebec and was assistant archivist when he died in 1941. Source: J.B.A. Allaire, Dictionnaire Biographique du Clergé Canadien-Français (1908), p. 104; Le Soleil, 1 octobre 1941, p. 3, 8; L'Action Catholique, 1 octobre 1941, p. 16.
} 
J'approuve bien votre projet de fonder une société canadienne d'histoire de l'église catholique. Quand on voit tout ce qui se fait aux États-Unis et ailleurs, pour promouvoir l'histoire du catholicisme, il faut avouer que nous sommes pas mal en retard sur ce point. ${ }^{87}$

To accomodate the two language groups, Caron made a simple suggestion - the new association could be organized in the same manner as, the Royal Society of Canada. It was this concept that Kenney adopted for the CCHA. With assistance from Kenney and his Archives colleague, Seraphin Marion, Caron canvassed prospective members in the province of Quebec and within a few months, he reported good progress: "many of the French speaking colleges and seminaries were expressing themselves as favourable to the project of a French section..." ${ }^{88}$ By April 1934, it was evident that enough interest existed in Quebec to warrant the formation of a separate section. Resolutions were subsequently prepared in order to amend the CCHA's constitution, and these were approved by the Executive Council in May 1934.

At the same time that the French section of the Association was evolving during the winter and spring of 1934, preparations for the CCHA's all-important first annual meeting to be held in Ottawa at the end of May were well underway. Kenney was determined to make a favourable impression on delegates and speakers were chosen with great care. Assuming that French-speaking members would form their own section, he designed the programme to strike a fine balance between English and French. The proceedings featured four papers in English and three in French: Mary Manley, "Dante, the Poet of the Liturgy", Rev. Edward Kelly, "Father John McKenna, Loyalist Chaplain', Rev. Brother Alfred, "The Hon. James Baby, First Catholic Member of the Executive Council of Upper Canada", and John Connolly, "Contemporary Recovery Policies against the Historical Background of Catholic Economic and Social Theory"; le chanoine Émile Chartier, "L'une des sources de l'apostolat canadien-français", le R.P. Thomas-M. Charland, «La mission de John Carroll au Canada en 1776 et l'interdit du P. Floquet », and J.F. Pouliot, «Liberté des cultes au Canada."

\footnotetext{
${ }^{87}$ SPU/CCHA, Caron to Kenney, 1 May 1933.

${ }^{88}$ Ibid., Kenney to Caron, 18 May 1933; Minutes of the Executive Council, 2 January 1934.
} 
Kenney also organized two luncheon discussions on themes that he was personally interested in, namely, the teaching of history in Catholic colleges and seminaries, and the work of the Association's Archives Committee. The conference was a huge success and Kenney was pleased with the results. A gala reception was held at the Public Archives building where guests were met by Prime Minister R.B. Bennett and the Secretary of State, C.H. Cahan. The papers were well received and the closing banquet was an impressive affair at the Chateau Laurier Hotel.

In a short speech following the conference dinner, Kenney reminded the delegates of the importance and relevance that he attached to a national association devoted to church history. He summarized the three major reasons why the CCHA had been established : first, he reflected on the Roman Catholic Church as an institution of "such tremendous importance in the history of the world" that there should be a society in Canada specially devoted to its study; second, he felt that there were a large number of "Catholic workers in history who feel the need of association with their fellow students"; and finally, he emphasized the need for "spreading historical information and interest among our people, a work which only a Catholic body can do, and a work that will make us better Catholics and also better citizens." 89

On that May evening in 1934, James Kenney and those who had assisted him were undoubtedly proud of their accomplishment. In the course of eighteen months, the Canadian Catholic Historical Association had been formed, an important French language section had been added to reflect the national character of the association, and a successful first conference had been held. In his first annual report as Secretary, Kenney paid tribute to those who had made the association possible and he concluded his remarks by putting this challenge to the membership:

The work that lies before us is vast. Even of the founders of the Church in Canada... much remains to be learned. Beyond the founders the surface of our work is hardly skimmed. There are no adequate guides to sources, very few of the bibliographical, biographical and other helps to historians are available, indeed not a large amount of scholarly work of any kind has yet been done. In the broader field of world history, the story of the Church's mission is simply inexhaustible. The harvest is rich, and the Canadian Catholic Historical Association is calling for laborers. ${ }^{90}$

\footnotetext{
${ }^{89}$ Kenney Papers, Speech Notes for Banquet, May 1934.

${ }^{90}$ CCHA, Report 1933-1934, Secretary's Report, p. 7.
} 
A complete biographical sketch of James Kenney's career as an archivist and scholar is beyond the scope of this paper. This account has focussed on James Kenney, the factors and events that molded him into the fascinating man that he was, and the circumstances that led to his decision to organize the Canadian Catholic Historical Association. It is necessary, however, to pick up the various threads of his story and carry them through to a conclusion.

At the Public Archives of Canada, Kenney had been Director of Historical Research and Publicity since 1926 and was one of the senior members of the staff. Evidence suggests, however, that he was not entirely satisfied with his lot, the lack of advancement being the most likely reason for his frustration. On at least two occasions, in 1929 and again in 1931, he enquired about employment in the United States, first as an historical researcher with the government itself, and secondly, as professor of Celtic History and Languages at the Catholic University of America. In 1932, when William Smith, Assistant Keeper of the Records at the Archives, passed away, Kenney applied for a promotion to his position, but the Conservative government of R.B. Bennett, grappling with the depression, decided not to appoint a replacement for Smith. The year 1935 brought a glimmer of hope. Arthur Doughty finally retired as Dominion Archivist at the age of seventy-five, and Kenney was appointed in his place on an acting basis.

Kenney served as Dominion Archivist from March 1935 until November 1937 . He desperately wanted the permanent appointment, and his supporters, including the English-speaking hierarchy, lobbied long and hard on his behalf with R.B. Bennett and after 1935, with William Lyon Mackenzie King. His chief rival, and long-time colleague on the Archives staff, Gustave Lanctot, could also draw upon influential support and he did. In November 1937, after months of procrastination, King appointed Lanctot Dominion Archivist. Kenney was bitterly disappointed. ${ }^{91}$

When Sources for the Early History of Ireland was published in 1929 , it was considered volume one of a two volume work. Kenney

\footnotetext{
${ }^{91}$ SPU/CCHA, Kenney to Latchford, 6 January 1938. The author has in preparation a paper describing the controversy surrounding the appointment of Lanctot over Kenney in 1937.
} 
had promised Columbia University Press a second volume dealing with secular source material. It is clear that he had completed some of his research as early as 1930, and scholars in Ireland and elsewhere were anxious to see more of his work. Other interests and preoccupations, however, intervened and volume two of Sources was never completed. For several years following the publication of his Irish book, Kenney devoted much of his time and energy to research and writing in the Canadian field. ${ }^{92}$ Serving on the executive of the American Catholic Historical Association in 1931-1932, and organizing the CC.HA in 1933 and 1934 occupied most of his spare time. In addition, the three year period in which he served as the Dominion Archivist was a hectic, uncertain time that drained him both physically and emotionally.

From the founding of the CCHA in 1933 until his untimely death in June 1946, one thing about James Kenney is very clear, and that was his singular devotion to the interests and well-being of the Association. Throughout these years, he served as English language Secretary of the Association. In this capacity he was responsible for editing the annual reports, he was the chairman of the programme committee for the annual meetings and he took a personal hand in selecting both the participants and the topics to be discussed, and he carried out all the other administrative duties of a growing association. And above all, he was the vital link between the English and French sections of the CCHA.

While membership held its own during the 1930's and even increased during the war years, in other areas of endeavour the CCHA's achievements had been less than spectacular. Many of its original aims and objectives remained undone and this worried Kenney, but he was not discouraged. On the contrary, after a dozen years of intense activity,

\footnotetext{
${ }^{92}$ Kenney's publications relating to the field of Canadian history include: "A British Secret Service Report on Canada, 1711," Canadian Historical Review, vol. 1, no. 1, March 1920, pp. 48-54; "The Career of Henry Kelsey," Royal Society of Canada, Transactions, Series III, Section 2, 1929, pp. 37-71; "Letter from an Edinburgh Student, 1804, With an Introduction and Notes," Queen's Quarterly, vol. xxxviii, no. 3, Summer 1931, pp. 461-477; The Founding of Churchill (London, 1932); "Relations Between Church and State in Canada Since the Cession of 1763," Catholic Historical Review, vol. xviii, no. 4, January 1933, pp. 439-471; "The Genealogy of Charles Lawrence, Governor of Nova Scotia," Canadian Historical Association, Historical Papers, 1932, pp. 81-86; and "The Public Records of the Province of Quebec, 17631791,"' Royal Society of Canada, Transactions, Series III, Section 2, 1940, pp. 87-133.
} 
he could take pride in a large membership with good representation from all regions of the country; the annual meetings were occasions for those interested in Canadian Catholic history to exchange ideas and research; the publication of the association's proceedings each year constituted a significant contribution to the historiography of Catholic history; and efforts were being made to improve the teaching of Catholic history in educational institutions. The accomplishments of the CCHA far outweighed any of its shortcomings.

Throughout his professional career as an archivist and historian, Kenney was a "seeker" of truth through historical research. As he told Archibishop James McGuigan of Toronto in September 1937, he was convinced that the study of history was specially important to Catholics

because of our acceptance of the testimony of tradition and because of our belief that the Church is the mystical body of Christ, making the history of the Church actually the story of His continuing life on earth. ${ }^{93}$

James Kenney encouraged Canadian Catholics to know themselves better by studying their past. To promote this ideal, he was the moving spirit behind the formation of the Canadian Catholic Historical Association in 1933. The very fact that in 1983 the Association celebrated fifty years of historical endeavour is a fitting tribute to its founder and inspiration, James Francis Kenney.

\footnotetext{
${ }^{93}$ Archives of the Archdiocese of Toronto, James C. McGuigan Papers, Kenney to McGuigan, 27 September 1937.
} 